\title{
Effects of dietary supplementation with an expressed fusion peptide bovine lactoferricin-lactoferrampin on performance, immune function and intestinal mucosal morphology in piglets weaned at age $21 \mathrm{~d}$
}

\author{
Zhiru Tang, Yulong Yin*, Youming Zhang, Ruilin Huang, Zhihong Sun, Tiejun Li, Wuying Chu, \\ Xiangfeng Kong, Lili Li, Meimei Geng and Qiang Tu \\ Laboratory of Animal Nutrition and Health and Key Laboratory of Subtropical Agro-Ecology, Institute of Subtropical Agriculture, \\ The Chinese Academy of Sciences, Changsha, Hunan 410125, China
}

(Received 3 January 2008 - Revised 14 May 2008 - Accepted 21 May 2008 - First published online 8 October 2008)

Lactoferrin has antimicrobial activity associated with peptide fragments lactoferricin (LFC) and lactoferrampin (LFA) released on digestion. These two fragments have been expressed in Photorhabdus luminescens as a fusion peptide linked to protein cipB. The construct cipB-LFC-LFA was tested as an alternative to antimicrobial growth promoters in pig production. Sixty piglets with an average live body weight of 5.42 (SEM 0.59 ) kg were challenged with enterotoxigenic Escherichia coli and randomly assigned to four treatment groups fed a maize-soyabean meal diet containing either no addition $(\mathrm{C})$, cipB at $100 \mathrm{mg} / \mathrm{kg}(\mathrm{C}+\mathrm{B})$, cipB-LFC-LFA at $100 \mathrm{mg} / \mathrm{kg}(\mathrm{C}+\mathrm{L})$ or colistin sulfate at $100 \mathrm{mg} / \mathrm{kg}(\mathrm{C}+\mathrm{CS})$ for $3 \mathrm{weeks}$. Compared with $\mathrm{C}$, dietary supplementation with $\mathrm{C}+\mathrm{L}$ for 3 weeks increased daily weight gain by $21 \%$, increased recovery from diarrhoea, enhanced serum glutathione peroxidase (GPx), peroxidase (POD) and total antioxidant content (T-AOC), liver GPx, POD, superoxide dismutase and T-AOC, Fe, total Fe-binding capacity, IgA, IgG and IgM levels $(P<0 \cdot 05)$, decreased the concentration of $E$. coli in the ileum, caecum and colon $(P<0.05)$, increased the concentration of lactobacilli and bifidobacteria in the ileum, caecum and colon $(P<0.05)$, and promoted development of the villus-crypt architecture of the small intestine. Growth performance was similar between $\mathrm{C}+\mathrm{L}-$ and $\mathrm{C}+\mathrm{CS}$-supplemented pigs. The present results indicate that LFC-LFA is an effective alternative to the feed antibiotic CS for enhancing growth performance in piglets weaned at age $21 \mathrm{~d}$.

Bovine lactoferricin-lactoferrampin: Weaned piglets: Growth performance: Immune function: Gut flora

During weaning, piglets are exposed to many stressors, including separation from the sow and the loss of sow milk. These abrupt changes in the piglets' diet often result in disturbances in digestive function and gastrointestinal disease ${ }^{(1)}$. Postweaning diarrhoea is a multifactorial condition that occurs after weaning, but is characterised by the proliferation of enterotoxigenic Escherichia coli (ETEC) $^{(2)}$.

The antibiotics that are used as growth promoters appear to act by reducing pathogenic bacteria and modifying the microflora in the gut of the animal ${ }^{(3)}$. However, dietary antibiotics lead to the presence of drug residues in edible animal products. Goblet cells containing sulfated mucin are less susceptible to bacterial degradation and have a more predominant function in the absence of an appropriately developed immune system ${ }^{(4)}$. Because antibiotic supplementation has been shown to reduce the number of these cells ${ }^{(4)}$, antibiotic supplementation may result in reduced innate immune function. Thus, considering both the safety of the consumer and the profitability for the farmer, alternatives to antibiotics are needed.
Bovine lactoferricin (LFC), which is released by gastric pepsin cleavage of bovine lactoferrin $(\mathrm{LF})^{(5-7)}$, is located on the 17-41 residues of the N-terminal part of LF, and shows more potent bactericidal and fungicidal activity than the native protein $\mathrm{LF}^{(7-10)}$. LF and LFC in the following text refer to the bovine forms. Several studies on LFC and related synthetic peptides have demonstrated that it shows broadspectrum activity against both Gram-positive and Gram-negative bacteria ${ }^{(8,11-13)}$. In addition, LF has been shown to have antifungal $^{(14,15)}$, antiviral ${ }^{(16,17)}$ and anti-tumour activity ${ }^{(13,18)}$, and to play a regulatory role in the adaptive immune response, as well as having anti-inflammatory properties ${ }^{(19,20)}$. In addition to $\mathrm{LFC}$, the $\mathrm{N}_{1}$-domain of $\mathrm{LF}$ contains a second antimicrobial peptide, designated lactoferrampin (LFA), with features of a hydrophobic domain containing tryptophan that are characteristic for antimicrobial peptides ${ }^{(21)}$. LFC and LFA have different antimicrobial spectra ${ }^{(22)}$. The fusion of LFC with LFA broadens their antimicrobial spectra in vitro $^{(23)}$. However, there are no reports on the effect of

Abbreviations: C, control; $\mathrm{C}+\mathrm{B}$, control supplemented with cipB; $\mathrm{C}+\mathrm{CS}$, control supplemented with colistin sulfate; $\mathrm{C}+\mathrm{L}$, control supplemented with cipBlactoferricin-lactoferrampin; CS, colistin sulfate; ETEC, enterotoxigenic Eschericia coli; GPx, glutathione peroxidase; LF, lactoferrin; LFA, lactoferrampin; LFC, lactoferricin; NOS, NO synthase; POD, peroxidase; T-AOC, total antioxidant content.

* Corresponding author: Dr Yulong Yin, fax +86 731461 2685, email yinyulong@yahoo.com.cn 
dietary supplementation with LFC on growth and health parameters in weaned piglets. Here we report such effects by dietary supplementation with a fusion protein of cipB and LFC-LFA (cipB-LFC-LFA, molecular weight $16300 \mathrm{Da})$ obtained by gene engineering technology at the Institute of Subtropical Agriculture (Chinese Academy of Sciences, Beijing, China) ${ }^{(23)}$. cipB protein, a Photorhabdus luminescens subsp. Akhurstii crystalline inclusion protein with a molecular weight of $11300 \mathrm{Da}$, was used as a positive control for cipB-LFC-LFA in the present study. Colistin sulfate (CS), an antibiotic that is popularly used in pig feed, was selected as an antibiotic treatment.

The primary objective of the present study was to determine the effect of dietary supplementation with the antimicrobial peptide bovine LFC-LFA replacing CS on growth performance, immune function, gut flora, intestinal mucosal morphology and antioxidant activity in piglets weaned at age $21 \mathrm{~d}$ and challenged with ETEC.

\section{Materials and methods}

\section{Materials}

cipB and cipB-LFC-LFA were provided by the Institute of Subtropical Agriculture (Chinese Academy of Sciences). They were obtained by the expression of the $\operatorname{cipB}$ and cipB-LFC-LFA genes in the expression host $P$. luminescens $\mathrm{TZR}_{001}$, as described previously ${ }^{(23)}$, and their purity is $98 \%$. ETEC 0149, 0141 and 064 were purchased from the China Institute of Veterinary Drug Control (Beijing, China).

\section{Animals, experimental design and diets}

Sixty Landrace $\times$ Yorkshire castrated piglets were obtained from a local commercial swine herd on weaning at $21 \mathrm{~d}$ of age. The piglets were challenged with the ETEC mixture of three serotypes (0149, 0141 and 064) at $22 \mathrm{~d}$ of age. Each ETEC was cultured in tryptic soya broth (Shanghai Sangon Biological Engineering Technology \& Service Co., Ltd, Shanghai, China) for $12 \mathrm{~h}$, mixed and given to each pig as a single oral dose $\left(10^{9}\right.$ cells $)$ as described previously ${ }^{(4)}$. Next day rectal swabs from each pig were plated on agar plates and scored as described previously: piglets scoring 0 $(0=$ have no $\beta$-haemolytic $E$. coli) were recorded as unaffected by diarrhoea; piglets scoring $\geq 1 \quad(\geq 1=$ have $\beta$-haemolytic $E$. coli) were recorded as affected by diarrhoea $^{(24)}$. Piglets scoring 3 ( $3=$ mainly $\beta$-haemolytic $E$. coli) had been challenged with ETEC; eight piglets scored below 3, and so a further dose of $E$. coli was again given to these pigs $\left(10^{10}\right.$ cells) by oral medication. All pigs were weighed (5.42 (SEM 0.59) $\mathrm{kg}$ ) and assigned randomly into one of four groups (fifteen pigs per group). The experimental piglets were randomly allocated to different pens (one piglet per pen) in a temperature-controlled room, as described previously $^{(25)}$. Feed and water were provided ad libitum.

The control diet formulated based on National Research Council requirements ${ }^{(26)}$ contained $59.37 \%$ maize, $25.00 \%$ soyabean meal, $4.00 \%$ fishmeal, $4.00 \%$ dried whey powder, $5.00 \%$ cream from bovine milk, $0.30 \%$ limestone, $1.10 \%$ monocalcium phosphate, $0.10 \%$ anti-mould agent, $0.02 \%$ antioxidant, $0.04 \%$ vitamin premix (providing the following per $\mathrm{kg}$ of complete feed: $11000 \mathrm{IU}(3300 \mu \mathrm{g})$ vitamin $\mathrm{A}$, $1100 \mathrm{IU}(27.5 \mu \mathrm{g})$ vitamin $\mathrm{D}_{3}, 22 \mathrm{IU}(14.67 \mu \mathrm{g})$ vitamin $\mathrm{E}$, $4 \mathrm{mg}$ menadione as dimethylpyrimidinol bisulfate, $0.03 \mathrm{mg}$ vitamin $\mathrm{B}_{12}, 28 \mathrm{mg}$ d-pantothenic acid, $33 \mathrm{mg}$ niacin and $0.08 \%$ choline chloride), $0.30 \%$ trace mineral premix (providing the following per $\mathrm{kg}$ of complete feed: $165 \mathrm{mg} \mathrm{Zn}$ $\left(\mathrm{ZnSO}_{4}\right), 165 \mathrm{mg} \mathrm{Fe}\left(\mathrm{FeSO}_{4}\right), 33 \mathrm{mg} \mathrm{Mn}\left(\mathrm{MnSO}_{4}\right), 16.5 \mathrm{mg}$ $\mathrm{Cu}\left(\mathrm{CuSO}_{4}\right), 297 \mu \mathrm{g} \mathrm{I}\left(\mathrm{CaI}_{2}\right)$ and $\left.297 \mu \mathrm{g} \mathrm{Se}\left(\mathrm{Na}_{2} \mathrm{SeO}_{3}\right)\right)$, $0.30 \%$ salt, $0.06 \%$ flavour, $0.23 \%$ L-lysine-HCl (Tanke Industry Co. Ltd, Guangzhou, China), 0.05\% L-methionine (Tanke Industry Co. Ltd) and $0.05 \%$ L-threonine (Tanke Industry Co. Ltd). The nutritional level of diets was as follows: $19.19 \%$ crude protein, $0.583 \% \mathrm{Ca}, 0.464 \% \mathrm{P}$, $1.198 \%$ lysine, $0.397 \%$ methionine, $0.850 \%$ threonine and 14.3 MJ digestible energy/kg feed. CS, cipB and cipBLFC-LFA were mixed with the vitamin premix, and then added to the diet, respectively. Each of the four groups of pigs was provided with one of the following diets: control (C), control supplemented with cipB at $100 \mathrm{mg} / \mathrm{kg}(\mathrm{C}+\mathrm{B})$, control supplemented with cipB-LFC-LFA at $100 \mathrm{mg} / \mathrm{kg}$ $(\mathrm{C}+\mathrm{L})$ and control supplemented with $\mathrm{CS}$ at $100 \mathrm{mg} / \mathrm{kg}$ $(\mathrm{C}+\mathrm{CS})$.

The pigs were individually weighed on an empty stomach at the end of the experiment. Feed intake and diarrhoea (score $\geq 1$ as described above) were recorded daily during the 3 -week period. At the end of the experiment, $10 \mathrm{ml}$ blood were drawn from the orbital sinus of five pigs per treatment with the closest body weight to obtain a serum sample and these animals were euthanised to evaluate intestinal microbiota and gut morphology. The animal protocol was approved by the Animal Care Committee of the Institute of Subtropical Agriculture.

\section{Assay of serum immune and biochemical index, and liver biochemical index concentrations}

Serum was obtained after blood centrifugation at $3000 \mathrm{rpm}$ for $20 \mathrm{~min}$ and stored at $-20^{\circ} \mathrm{C}$. Total $\operatorname{IgA}, \operatorname{IgM}$ and IgG were determined in serum using radial immuno-diffusion kits (Triple J Farms, Bellingham, WA, USA). Serum Fe and total Fe-binding capacity were determined colorimetrically using reagent kits (Nanjing Jiancheng Bioengineering Institute, Nanjing, China). GPx, NO synthase (NOS), peroxidase (POD), superoxide dismutase and total antioxidant content (T-AOC) were determined in serum and liver by colorimetric methods described with reagent kits supplied as above.

\section{Analysis of gut microbiota}

Intestinal digesta of the distal ileum, caecum and mid-colon were collected aseptically. Intestinal bacteria were evaluated using conventional culture methods as described previously $^{(27)}$. For conventional culture, intestinal digesta were diluted with sterile phosphate buffer solution. For lactic acid bacteria, De Man-Rogosa-Sharp (MRS) agar plates were incubated anaerobically at $37^{\circ} \mathrm{C}$ for $48 \mathrm{~h}$ (Oxoid, Basingstoke, Hants, UK). For bifidobacteria, lipovitellin-salt-mannitolcysteine (LSM-C) agar plates were incubated anaerobically at $37^{\circ} \mathrm{C}$ for $48 \mathrm{~h}$ (Oxoid). For coliforms, MacConkey agar plates were incubated aerobically at $37^{\circ} \mathrm{C}$ for $24 \mathrm{~h}$ (Oxoid). 


\section{Analysis of gut morphology}

Gut samples for the evaluation of histology were collected from the jejunum, $1 \mathrm{~m}$ posterior to the pyloric sphincter, and fixed in $10 \%$ buffered formalin solution. Serial sections $(5 \mu \mathrm{m})$ were cut and stained with periodic acid-Schiff ${ }^{(28)}$ to evaluate villus morphology. Villus height was considered to be the distance from the crypt opening to the tip of the villus, while crypt depth was measured from the base of the crypt to the level of the opening ${ }^{(29)}$.

\section{Data treatment and analysis}

Feed conversion $=$ feed intake/weight gain.

Diarrhoea percentage $(\%)=$ daily total number of piglets with diarrhoea of each treatment/(daily total number of piglets of each treatment) $\times 100$.

Intestinal bacterial data were log-transformed (log 10 colonyforming units/g digesta).

\section{Statistical analysis}

All data are presented as means and with their standard errors. All data except for diarrhoea percentage from the experiment were subjected to one-way ANOVA using the general linear model (GLM) procedure of SAS statistical software (SAS Institute, Inc., Cary, NC, USA) according to a completely randomised one-factorial design. The diarrhoea percentages from the experiment were subjected to two-way (treatment and time) ANOVA using the GLM procedures of SAS statistical software (SAS Institute). Duncan's multiplerange test was performed to identify differences among groups. Significance was set at $P<0 \cdot 05$.

\section{Results}

\section{Feed intake, growth performance and diarrhoea percentage}

Piglets fed the $\mathrm{C}+\mathrm{L}$ or $\mathrm{C}+\mathrm{CS}$ diet had higher daily weight gain and daily feed intake $(P<0.05)$ than pigs fed the $\mathrm{C}$ or $\mathrm{C}+\mathrm{B}$ diet (Table 1). Piglets fed the $\mathrm{C}+\mathrm{L}$ or $\mathrm{C}+\mathrm{CS}$ diet had lower faecal scores $(P<0 \cdot 05)$ than piglets fed the $\mathrm{C}$ or $\mathrm{C}+\mathrm{B}$ diet (Table 1). However, there were no differences in growth performance and faecal score between pigs fed the $\mathrm{C}+\mathrm{L}$ and $\mathrm{C}+\mathrm{CS}$ diets $(P>0.05)$. There were also no differences in growth performance and faecal score between pigs fed the $\mathrm{C}$ and $\mathrm{C}+\mathrm{B}$ diets. Feed conversion did not differ among the four groups $(P>0.05)$ (Table 1). Compared with the $\mathrm{C}$ and $\mathrm{C}+\mathrm{B}$ diets, dietary supplementation with cipB-LFC-LFA or CS increased recovery from diarrhoea $(P<0.05)$ (Fig. 1). The effect of dietary supplementation with cipB-LFC-LFA on the incidence of diarrhoea in piglets weaned at age $21 \mathrm{~d}$ was the same as that with CS $(P>0.05)$ (Fig. 1).

\section{Gut flora}

Dietary supplementation with cipB-LFC-LFA or CS decreased the concentration of $E$. coli in the ileum, caecum and colon $(P<0 \cdot 05)$ and increased the concentration of lactobacilli and bifidobacteria in the ileum, caecum and colon $(P<0.05)$ compared with the $\mathrm{C}$ and $\mathrm{C}+\mathrm{B}$ groups (Table 2$)$. The concentration of bifidobacteria in the ileum of the $\mathrm{C}+\mathrm{L}$ group was lower than that in the $\mathrm{C}+\mathrm{CS}$ group $(P<0.05)$ (Table 2). However, there were no differences in the concentration of $E$. coli and lactobacilli in the ileum, caecum and colon, or in the concentration of bifidobacteria in the caecum and colon between the $\mathrm{C}+\mathrm{L}$ and $\mathrm{C}+\mathrm{CS}$ groups $(P>0.05)$ (Table 2$)$. There were also no differences in the concentration of $E$. coli, lactobacilli and bifidobacteria in the ileum, caecum and colon between the $\mathrm{C}$ and $\mathrm{C}+\mathrm{B}$ groups (Table 2).

\section{Intestinal mucosal morphology}

The villus height of the jejunum and ileum in the $\mathrm{C}+\mathrm{L}$ group was greater than that in the $\mathrm{C}$ and $\mathrm{C}+\mathrm{B}$ groups $(P<0 \cdot 05)$, and the villus height:crypt depth ratio of the jejunum in the $\mathrm{C}+\mathrm{L}$ group was greater than that in the $\mathrm{C}$ group $(P<0.05)$ (Table 3). However, there were no differences in crypt depth between the $\mathrm{C}+\mathrm{L}$ group and the other groups $(P>0.05)$ (Table 3). There were also no differences in crypt depth or villus height:crypt depth ratio in the jejunum between the $\mathrm{C}+\mathrm{L}$ group and the $\mathrm{C}+\mathrm{CS}$ group $(P>0.05)$ (Table 3$)$.

\section{Indices of antioxidant levels in serum and liver}

As shown in Table 4, compared with the $\mathrm{C}$ and $\mathrm{C}+\mathrm{B}$ groups, pigs fed $\mathrm{C}+\mathrm{L}$ or $\mathrm{C}+\mathrm{CS}$ had higher levels of GPx, POD and T-AOC in both serum and liver $(P<0 \cdot 05)$. Serum POD and $\mathrm{T}$-AOC in the $\mathrm{C}+\mathrm{L}$ group were lower than those in the $\mathrm{C}+\mathrm{CS}$ group $(P<0 \cdot 05)($ Table 4$)$.

Table 1. Effects of supplementary fusion protein cipB-lactoferricin-lactoferrampin $(C+L)$ compared with an unsupplemented basal diet $(\mathrm{C})$, a control of the basal diet supplemented with cipB alone $(\mathrm{C}+\mathrm{B})$ or the basal diet supplemented with the antibiotic colistin sulfate $(C+C S)$ on growth performance in piglets weaned at age $21 \mathrm{~d}$

(Mean values and pooled standard errors for fifteen pigs per treatment)

\begin{tabular}{|c|c|c|c|c|c|c|}
\hline Diet... & $C$ & $C+B$ & $C+L$ & $\mathrm{C}+\mathrm{CS}$ & SEM & $P$ \\
\hline Initial weight (kg) & $5 \cdot 39$ & $5 \cdot 42$ & 5.44 & $5 \cdot 38$ & 0.15 & 0.993 \\
\hline Final weight $(\mathrm{kg})$ & $10 \cdot 3^{b}$ & $10 \cdot 5^{\mathrm{b}}$ & $11 \cdot 5^{\mathrm{a}}$ & $11 \cdot 6^{a}$ & 0.28 & 0.002 \\
\hline Daily weight gain (g/d) & $233^{b}$ & $239^{b}$ & $289^{a}$ & $292^{a}$ & $10 \cdot 00$ & $<0.001$ \\
\hline Daily feed intake (g/d) & $428^{b}$ & $416^{b}$ & $499^{a}$ & $506^{a}$ & $14 \cdot 50$ & $<0.001$ \\
\hline Feed conversion (g feed/g weight gain) & 1.85 & 1.75 & $1 \cdot 74$ & $1 \cdot 72$ & 0.04 & 0.214 \\
\hline Faecal score & $1.93^{\mathrm{a}}$ & $1 \cdot 78^{a}$ & $0 \cdot 87^{b}$ & $0.80^{\mathrm{b}}$ & 0.17 & 0.001 \\
\hline
\end{tabular}

${ }^{a, b}$ Mean values within a row with unlike superscript letters were significantly different $(P<0.05)$. 


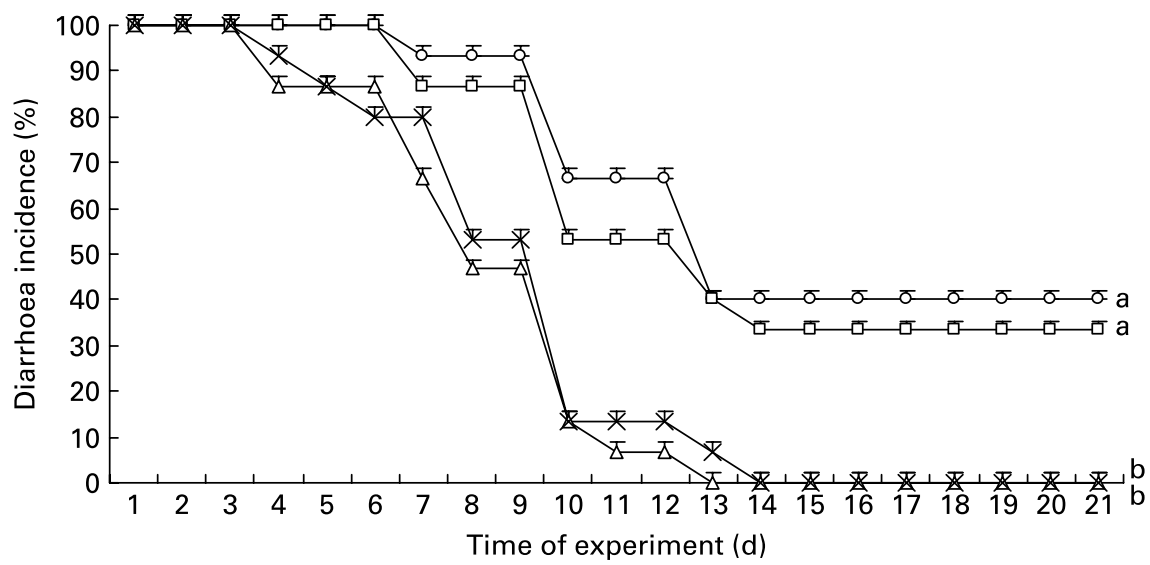

Fig. 1. Effects of supplementary fusion protein cipB-lactoferricin-lactoferrampin $(-\Delta-)$ compared with an unsupplemented basal diet (-O-), a control of the basal diet supplemented with cipB alone $(-\square-)$ or the basal diet supplemented with the antibiotic colistin sulfate $(-x-)$ on the incidence of diarrhoea in piglets weaned at age $21 \mathrm{~d}$. Values are means with their standard errors $(2 \cdot 14)$ represented by vertical bars. ${ }^{\mathrm{a}, \mathrm{b}}$ Lines with unlike letters were significantly different $(P<0 \cdot 05)$.

Table 2. Effects of supplementary fusion protein cipB-lactoferricinlactoferrampin $(\mathrm{C}+\mathrm{L})$ compared with an unsupplemented basal diet (C), a control of the basal diet supplemented with cipB alone $(C+B)$ or the basal diet supplemented with the antibiotic colistin sulfate $(C+C S)$ on the gut flora of piglets weaned at age $21 \mathrm{~d}$ (log 10 colony-forming units/g digesta)

(Mean values and pooled standard errors for five pigs per treatment)

\begin{tabular}{|c|c|c|c|c|c|c|}
\hline Diet... & C & $C+B$ & $C+L$ & $\mathrm{C}+\mathrm{CS}$ & SEM & $P$ \\
\hline \multicolumn{7}{|c|}{ Escherichia coli } \\
\hline Ileum & $6 \cdot 87^{\mathrm{a}}$ & $6 \cdot 88^{a}$ & $5 \cdot 39^{b}$ & $5 \cdot 33^{b}$ & 0.42 & $<0.001$ \\
\hline Caecum & $7 \cdot 96^{a}$ & $7 \cdot 90^{\mathrm{a}}$ & $6 \cdot 28^{b}$ & $6 \cdot 31^{b}$ & 0.32 & $<0.001$ \\
\hline Colon & $8 \cdot 11^{a}$ & $8 \cdot 10^{\mathrm{a}}$ & $7 \cdot 60^{b}$ & $7 \cdot 46^{\mathrm{b}}$ & 0.52 & $<0.001$ \\
\hline \multicolumn{7}{|l|}{ Lactobacilli } \\
\hline Ileum & $7 \cdot 29^{b}$ & $7 \cdot 32^{b}$ & $7 \cdot 87^{a}$ & $7 \cdot 94^{a}$ & 0.44 & $<0.001$ \\
\hline Caecum & $7 \cdot 26^{b}$ & $7 \cdot 31^{b}$ & $8 \cdot 86^{a}$ & $8 \cdot 78^{a}$ & 0.42 & $<0.001$ \\
\hline Colon & $7 \cdot 53^{c}$ & $7 \cdot 47^{\mathrm{c}}$ & $8.94^{a}$ & $8 \cdot 81^{a}$ & 0.41 & $<0.001$ \\
\hline \multicolumn{7}{|c|}{ Bifidobacteria } \\
\hline Ileum & $6 \cdot 75^{\mathrm{C}}$ & $6 \cdot 93^{\mathrm{C}}$ & $8 \cdot 39^{b}$ & $8 \cdot 50^{a}$ & 0.34 & $<0.001$ \\
\hline Caecum & $7 \cdot 99^{b}$ & $8 \cdot 00^{b}$ & $9 \cdot 10^{\mathrm{a}}$ & $9 \cdot 15^{\mathrm{a}}$ & 0.22 & $<0.001$ \\
\hline Colon & $8 \cdot 01^{b}$ & $8 \cdot 05^{b}$ & $9 \cdot 19^{a}$ & $9 \cdot 10^{\mathrm{a}}$ & 0.43 & $<0.001$ \\
\hline
\end{tabular}

a,b,c Mean values within a row with unlike superscript letters were significantly different $(P<0.05)$.

Serum iron, total iron-binding capacity and immunoglobulins

Dietary supplementation with cipB-LFC-LFA or CS increased serum $\mathrm{Fe}$, total Fe-binding capacity and $\mathrm{IgA}, \mathrm{IgG}$, and $\mathrm{IgM}$ relative to the animals in the $\mathrm{C}$ and $\mathrm{C}+\mathrm{B}$ groups $(P<0.05)$
(Table 5). Serum IgM in the $\mathrm{C}+\mathrm{L}$ group was lower than that in the $\mathrm{C}+\mathrm{CS}$ group $(P<0 \cdot 05)$ (Table 5$)$.

\section{Discussion}

cipB-LFC-LFA is a fusion protein of the cipB protein and the LFC-LFA peptide which is released by pepsin in the animal stomach. Because the present results showed that dietary supplementation with cipB had no effects on growth performance, immune function, gut flora and intestinal mucosal morphology in piglets weaned at age $21 \mathrm{~d}$ and challenged with ETEC, we conclude that LFC-LFA is responsible for the observed effects on growth performance, immune function, gut flora and intestinal mucosal morphology.

The results also showed that dietary supplementation with LFC-LFA decreased the concentration of $E$. coli while it increased both lactobacilli and bifidobacteria in the gut. The observed faecal score and diarrhoea results were a reflection of this. The effects of the treatment on bacterial concentration are related to the occurrence of diarrhoea ${ }^{(30)}$. Dietary supplementation with LFC-LFA reduced faecal score and the percentage of diarrhoea in the present experiment, so the increase in lactobacilli and bifidobacteria concentrations could result, at least partly, from increased DM concentration due to reduced diarrhoea.

Table 3. Effects of supplementary fusion protein cipB-lactoferricin-lactoferrampin (C $+\mathrm{L})$ compared with an unsupplemented basal diet (C), a control of the basal diet supplemented with cipB alone $(C+B)$ or the basal diet supplemented with the antibiotic colistin sulfate $(C+C S)$ on the intestinal mucosal morphology in piglets weaned at age $21 \mathrm{~d}$

(Mean values and pooled standard errors for five pigs per treatment)

\begin{tabular}{|c|c|c|c|c|c|c|c|}
\hline Diet... & & C & $C+B$ & $C+L$ & $\mathrm{C}+\mathrm{CS}$ & SEM & $P$ \\
\hline \multirow[t]{2}{*}{ Villus height $(\mu \mathrm{m})$} & Jejunum & $724^{b}$ & $700^{b}$ & $830^{a}$ & $866^{a}$ & 47.41 & $<0.001$ \\
\hline & Ileum & $536^{b}$ & $546^{b}$ & $616^{a}$ & $630^{a}$ & $29 \cdot 22$ & 0.002 \\
\hline \multirow{2}{*}{ Crypt depth $(\mu \mathrm{m})$} & Jejunum & 254 & 224 & 234 & 228 & $22 \cdot 31$ & 0.335 \\
\hline & Ileum & 234 & 244 & 228 & 236 & $16 \cdot 73$ & 0.637 \\
\hline \multirow[t]{2}{*}{ Villus height:crypt depth ratio } & Jejunum & $2 \cdot 88^{\mathrm{C}}$ & $3 \cdot 16^{b, c}$ & $3 \cdot 60^{a, b}$ & $3 \cdot 81^{a}$ & 0.34 & 0.008 \\
\hline & Ileum & $2 \cdot 31^{a, b}$ & $2 \cdot 25^{b}$ & $2 \cdot 72^{\mathrm{a}}$ & $2 \cdot 69^{a, b}$ & 0.13 & 0.066 \\
\hline
\end{tabular}

${ }^{\mathrm{a}, \mathrm{b}, \mathrm{c}}$ Mean values within a row with unlike superscript letters were significantly different $(P<0.05)$. 
Table 4. Effects of supplementary fusion protein cipB-lactoferricin-lactoferrampin $(C+L)$ compared with an unsupplemented basal diet $(C)$, a control of the basal diet supplemented with cipB alone $(C+B)$ or the basal diet supplemented with the antibiotic colistin sulfate $(C+C S)$ on serum and liver concentration of glutathione peroxidase (GPx), nitrogen oxide synthase (NOS), peroxidase (POD), superoxide dismutase (SOD) and total antioxidant content (T-AOC) in piglets weaned at age $21 \mathrm{~d}$

(Mean values and pooled standard errors for five pigs per treatment)

\begin{tabular}{|c|c|c|c|c|c|c|}
\hline Diet... & C & $C+B$ & $C+L$ & $C+C S$ & SEM & $P$ \\
\hline \multicolumn{7}{|l|}{ Serum } \\
\hline $\mathrm{GPx}(\mathrm{U} / \mathrm{ml})$ & $372^{b}$ & $374^{\mathrm{b}}$ & $503^{a}$ & $480^{a}$ & $9 \cdot 10$ & $<0.001$ \\
\hline $\mathrm{NOS}(\mathrm{U} / \mathrm{ml})$ & $19 \cdot 2$ & $20 \cdot 8$ & 20.6 & 19.7 & 0.85 & 0.525 \\
\hline POD $(\mathrm{U} / \mathrm{ml})$ & $23 \cdot 3^{c}$ & $24 \cdot 3^{c}$ & $34 \cdot 8^{b}$ & $38 \cdot 1^{\mathrm{a}}$ & 1.00 & $<0.001$ \\
\hline $\mathrm{SOD}(\mathrm{U} / \mathrm{ml})$ & $33 \cdot 8$ & $34 \cdot 1$ & $37 \cdot 7$ & $35 \cdot 3$ & $2 \cdot 17$ & 0.579 \\
\hline T-AOC (U/ml) & $1.46^{\mathrm{c}}$ & $1.47^{\mathrm{c}}$ & $2.46^{\mathrm{b}}$ & $2.93^{\mathrm{a}}$ & $0 \cdot 12$ & $<0.001$ \\
\hline \multicolumn{7}{|l|}{ Liver } \\
\hline GPx $(\mathrm{U} / \mathrm{mg})$ & $311^{b}$ & $329^{b}$ & $454^{a}$ & $437^{a}$ & 14.89 & $<0.001$ \\
\hline NOS (U/mg) & 63.1 & 63.0 & 65.5 & $66 \cdot 0$ & $2 \cdot 89$ & 0.828 \\
\hline $\mathrm{POD}(\mathrm{U} / \mathrm{mg})$ & $525^{\mathrm{b}}$ & $565^{\mathrm{b}}$ & $701^{a}$ & $674^{\mathrm{a}}$ & $26 \cdot 10$ & 0.003 \\
\hline $\mathrm{SOD}(\mathrm{U} / \mathrm{mg})$ & $44 \cdot 3^{\mathrm{b}}$ & $44 \cdot 3^{b}$ & $47.9^{a}$ & $47 \cdot 5^{a}$ & 0.88 & 0.018 \\
\hline T-AOC (U/mg) & $0 \cdot 17^{\mathrm{b}}$ & $0.22^{\mathrm{b}}$ & $0.46^{\mathrm{a}}$ & $0.40^{\mathrm{a}}$ & 0.03 & $<0.001$ \\
\hline
\end{tabular}

${ }^{\mathrm{a}, \mathrm{b}, \mathrm{c}}$ Mean values within a row with unlike superscript letters were significantly different $(P<0.05)$.

Some previous studies have also reported that LF and LFC had positive effects on pathogenic and beneficial bacteria. Arnold et al. ${ }^{(31)}$ found that LFC under $50 \mu \mathrm{M}$ could directly kill $E$. coli $^{(31)}$. Ellison et al. reported that the concentrations of lactobacilli and bifidobacteria in infants fed breast milk were significantly greater than those in infants fed milk powder; this difference is believed to be related to the presence of LFC in breast milk ${ }^{(32)}$. LFC, a cationic peptide with broad antibacterial activity, shows membrane-disruptive properties ${ }^{(33)}$, and contains a high proportion of basic amino acid residues. It has been demonstrated that the highly cationic property of LF is responsible for the ability of LF to bind glycosaminoglycan $^{(34)}$, heparin and lipopolysaccharide ${ }^{(35)}$. It has been suggested that LF exerts its effect at the surface of the bacterial membrane ${ }^{(14)}$ and the positive charges within the peptide are thought to promote interaction with membrane components. As the number of positive charges increases, the number of interactions with negatively charged membrane components also increases ${ }^{(9,36)}$. LFA has a hydrophobic domain containing tryptophan, which is involved in the insertion of hydrophobic peptides into cell membranes ${ }^{(21)}$.

Table 5. Effects of supplementary fusion protein cipB-lactoferricinlactoferrampin $(\mathrm{C}+\mathrm{L})$ compared with an unsupplemented basal diet (C), a control of the basal diet supplemented with cipB alone $(C+B)$ or the basal diet supplemented with the antibiotic colistin sulfate $(C+C S)$ on serum $\mathrm{Fe}^{2+}$, total iron-binding capacity and immunoglobulins in piglets weaned at age $21 \mathrm{~d}$

(Mean values and pooled standard errors for five pigs per treatment)

\begin{tabular}{|c|c|c|c|c|c|c|}
\hline Diet... & C & $C+B$ & $C+L$ & $C+C S$ & SEM & $P$ \\
\hline $\mathrm{Fe}^{2+}(\mu \mathrm{mol} / \mathrm{l})$ & $44 \cdot 7^{b}$ & $46 \cdot 8^{b}$ & $67 \cdot 5^{\mathrm{a}}$ & $61 \cdot 3^{\mathrm{a}}$ & 3.69 & 0.001 \\
\hline Total & $75 \cdot 0^{\mathrm{b}}$ & $78 \cdot 5^{\mathrm{b}}$ & $101 \cdot 3^{\mathrm{a}}$ & $87 \cdot 6^{\mathrm{a}, \mathrm{b}}$ & 5.29 & 0.013 \\
\hline \multicolumn{7}{|c|}{ Fe-binding capacity (\%) } \\
\hline $\operatorname{lgA}(\mathrm{mg} / \mathrm{l})$ & $1.7^{\mathrm{b}}$ & $2 \cdot 0^{\mathrm{b}}$ & $4.4^{a}$ & $4 \cdot 8^{\mathrm{a}}$ & 0.4 & $<0.001$ \\
\hline $\operatorname{lgG}(\mathrm{mg} / \mathrm{l})$ & $1990^{b}$ & $2150^{b}$ & $2560^{a}$ & $2730^{\mathrm{a}}$ & 106 & $<0.001$ \\
\hline $\operatorname{lgM}(\mathrm{mg} / \mathrm{l})$ & $374^{c}$ & $380^{c}$ & $465^{\mathrm{b}}$ & $567^{a}$ & $17 \cdot 8$ & $<0.001$ \\
\hline
\end{tabular}

${ }^{a, b, c}$ Mean values within a row with unlike superscript letters were significantly different $(P<0.05)$.
A possible mechanism by which LFC-LFA exerts the effects observed in the present study is that the fusion of LFC with LFA enhances antimicrobial ability.

The structure of the villus-crypt architecture of the small intestine can reflect the health of the small intestine. After weaning, the height of gut villi in piglets is reduced and the depth of the crypt is increased ${ }^{(1)}$. The present study showed that LFCLFA can increase the height of the villi in the jejunum and ileum along with the villus height:crypt depth ratio in the jejunum and ileum. This suggests that LFC-LFA can promote the development of villus-crypt architecture of the intestinal mucosa. Humphrey et al. ${ }^{(37)}$ reported that the addition of rice that expressed the LF gene to a broiler diet increased the height of villi in the duodenum ${ }^{(37)}$. A toxin produced by ETEC in the gut can cause inflammation of the intestinal mucosa and diarrhoea ${ }^{(38)}$. Morphological changes in the small intestine, such as shortening of the villi and an increase in crypt depth, are closely related to the presence in the gut of the toxin produced by ETEC $^{(39)}$. The fact that dietary LFC-LFA increased the height of the gut villi in piglets may be related to the fact that LFC-LFA can decrease the concentration of $E$. coli and increase those of lactobacilli and bifidobacteria in the gut.

Oxidative stress is characterised by: (a) depletion of intracellular antioxidants (largely glutathione) and free-radical scavengers (vitamins $\mathrm{E}$ and $\mathrm{C}$ ); (b) inhibition of the activity of various enzymes that contribute to the metabolism and detoxification of reactive oxygen species, such as GPx, glutathione reductase, glutathione transferase, catalase and superoxide dismutase; (c) increased production of reactive oxygen species (superoxide anion radical, $\mathrm{H}_{2} \mathrm{O}_{2}$, peroxyl radical, hydroxyl radical, NO, peroxynitrite radical, etc) ${ }^{(40)}$. Changes in the activities of antioxidant enzymes (GPx, NOS, POD and superoxide dismutase) can be considered as biomarkers of the antioxidant response ${ }^{(41)}$. The present study showed that dietary LFC-LFA increased serum antioxidant enzyme activities (GPx, POD and T-AOC) and liver antioxidant enzyme activities (GPx, POD, superoxide dismutase and T-AOC) in piglets. LFC-LFA exerts antioxidant activity by binding $\mathrm{Fe}^{2+}$, which can activate oxygen free radicals. 
Therefore, the binding of LF and its peptides with $\mathrm{Fe}^{2+}$ in the gut can prevent lipid oxidation and the production of free radicals caused by $\mathrm{Fe}^{2+42)}$. The binding of $\mathrm{LFC}$ with $\mathrm{Fe}^{2+}$ can effectively decrease the transformation of peroxide to oxygen free radicals, and LFC can also reduce the oxidation of ascorbic acid and tryptophan ${ }^{(43)}$. The enzymes work together to eliminate reactive oxygen species and small deviations of their physiological concentrations could have a dramatic effect on the resistance of cellular lipids, proteins and DNA to oxidative damage. These effects imply that the bioactive peptides of the fusion protein under study are taken up by the intestinal mucosa, a point which remains to be demonstrated.

Weaning stress can temporarily reduce growth $^{(1,44)}$. The present study showed that dietary LFC-LFA can increase serum $\operatorname{IgA}, \operatorname{IgG}$ and $\operatorname{IgM}$ levels, decrease the incidence of diarrhoea, and improve daily weight gain and daily feed intake in piglets. Debbabi et al. reported that bovine LF given orally to mice increased total $\operatorname{IgA}$ and $\mathrm{IgG}$ in intestinal secretions and LF-specific IgA and IgG in serum ${ }^{(45)}$. Prgomet et al. ${ }^{(46)}$ also reported that calves given LF maintained a higher total $\mathrm{IgG}$ in serum compared with the post-colostral decline in control calves but did not affect total serum IgG by the end of the experiment ${ }^{(46)}$. The present study showed that the changes in Ig concentrations observed with both $\mathrm{C}+\mathrm{L}$ and $\mathrm{C}+\mathrm{CS}$ are secondary to changes in the microbial populations, with decreased $E$. coli but increased lactobacilli and bifidobacteria. Shu et al. ${ }^{(47)}$ demonstrated that feeding piglets with a probiotic Bifidobacterium lactis resulted in increased rotavirus-specific and $E$. coli-specific $\operatorname{IgA}, \operatorname{IgG}$ and $\operatorname{IgM}$ in faecal supernatant fractions ${ }^{(47)}$. This literature indicates that LF or its digestion products can influence the adaptive immune system, either directly or indirectly via alteration of the gut microflora, but the Ig responses are mainly elicited from intestinal mucosal cells, with increased secretion into the intestine and much less change, if any, in the systemic response. The improvement of daily food intake and daily weight gain by LFC-LFA was related to the fact that LFCLFA can improve health parameters such as immune function and gut health in the present experiment. The improvement in growth performance by LFC-LFA can be attributed to the fact that LF and LFC have been shown to have antibacterial $^{(5,31)}$ and antiviral activities ${ }^{(22)}$, regulate the immune response $^{(48,49)}$ and improve the absorption of $\mathrm{Fe}^{(30,50,51)}$. Similarly, LFC-LFA might improve growth performance in piglets weaned at age $21 \mathrm{~d}$ challenged with ETEC through an antibacterial effect, the regulation of immune function, improvement of the absorption of $\mathrm{Fe}$ and a reduction in the incidence of diarrhoea.

Based on effect of LFC-LFA or CS on growth performance, immune function, gut flora, intestinal mucosal morphology and antioxidant activity in piglets weaned at age $21 \mathrm{~d}$ challenged with ETEC, the present results suggest that LFC-LFA could replace the antibiotic CS. Technology for the production of LFC-LFA has already been established. The pasteurising conditions during processing of LFC-LFAsupplemented products have also been assessed. It is now possible to supply a larger amount of LFC-LFA than the current supply. Using this product, various beneficial effects of LFC-LFA as a feed additive have been demonstrated and this has enabled us to use LFC-LFA in a large number of fields. However, regarding the safety of the consumer, possible side effects of LFC-LFA as a GM organism's product on both target animals and humans remain to be evaluated further before large-scale application. In addition, the use of LFC-LFA in combination with other additives needs to be considered.

\section{Acknowledgements}

This research was jointly supported by grants from the Program for the National Basic Research Program of China (2004CB117502), National Natural Science Foundation of China (NSFC) (30700581, 30771558 and 30671517), the Chinese Academy of Science Knowledge Innovation Project (KSCX2-YW-N-022), Fund of Agricultural Science and Technology Outcome Application (2006GB24910468), the Program for the Latest Research Field of Youth Talents in Institute of Subtropical Agriculture, the Chinese Academy of Sciences (ISACX-LYQY-QN-0701), Special Research Fund Scholarship Gainer of the Chinese Academy of Sciences (0723022110), Hunan Province Key Project (2007FJ1003), National Scientific and Technology Supporting Projects (2006BAD1 2B07-6, 2006BAD12B02-5-2), Guang Dong Province Project (2006B200330005) and Program for Changjiang Scholars and Innovative University Research Team (65 292 and IRT0540). The authors have no conflicts of interest to declare. Y. Y. was in charge of the whole trial. Y.Z. gave the original idea of testing this fusion peptide in weaned pigs. Z. T. conducted the animal experiment and wrote the whole of the paper. R. H., Z. S., L. L., T. L., W. C., X. K., M. G. and Q. T. assisted with the animal trial and chemical analyses.

\section{References}

1. Pluske JR, Hampson DJ \& Williams IH (1997) Factors influencing the structure and function of the small intestine in the weaned pig: a review. Livest Prod Sci 51, 215-236.

2. Hopwood DE, Pluske JR \& Hampson DJ (2005) Dietary manipulation of infectious bowel disease. In Biology of Nutrition in Growing Animals, pp. 365-385 [R Mosenthin, J Zentek and T Zebrowska, editors]. Amsterdam: Elsevier Ltd.

3. Radostits OM, Leslie KE \& Fetrow J (1994) Planned animal health and production in swine herds. In Herd Health. Food Animal Production Medicine, 2nd ed., pp. 435-526 [OM Radostits, editor]. London: Saunders.

4. Davis ME, Brown DC, Baker A, Bos K, Dirain MS, Halbrook E, Johnson ZB, Maxwell C \& Rehberger T (2007) Effect of directfed microbial and antibiotic supplementation on gastrointestinal microflora, mucin histochemical characterization, and immune populations of weanling pigs. Livest Sci 108, 249-253.

5. Bellamy W, Takase M, Yamauchi K, Wakabayashi H, Kawase K \& Tomita M (1992) Identification of the bactericidal domain of lactoferrin. Biochim Biophys Acta 1121, 130-136.

6. Kuwata H, Yip TT, Tomita M \& Hutchens TW (1998) Direct evidence of the generation in human stomach of an antimicrobial peptide domain (lactoferricin) from ingested lactoferrin. Biochim Biophys Acta 1429, 129-141.

7. Kuwata H, Yip TT, Yamauchi K, Teraguchi S, Hayasawa H \& Tomita M (1998) The survival of ingested lactoferrin in the gastrointestinal tract of adult mice. J Biochem 334, 321-323.

8. Bellamy W, Takase M, Wakabayashi H, Kawase K \& Tomita M (1992) Antibacterial spectrum of lactoferricin B, a potent 
bactericidal peptide derived from the $\mathrm{N}$-terminal region of bovine lactoferrin. J Appl Bacteriol 73, 472-479.

9. Hwang PM, Zhou N, Shan X, Arrowsmith CH \& Vogel HJ (1998) Three-dimensional solution structure of lactoferricin B, an antimicrobial peptide derived from bovine lactoferrin. Biochemistry 37, 4288-4298.

10. Tomita M, Takase M, Bellamy W \& Shimamura S (1994) A review: the active peptide of lactoferrin. Acta Paediatr Jpn 36, 585-591.

11. Groenink J, Walgreen-Weterings E, van't Hof W, Veerman ECI \& Nieuw AAV (1999) Cationic amphipathic peptides, derived from bovine and human lactoferrins, with antimicrobial activity against oral pathogens. FEMS Microbiol Lett 179, 217-222.

12. Wakabayashi $\mathrm{H}$, Matsumoto $\mathrm{H}$, Hashimoto $\mathrm{K}$, Teraguchi $\mathrm{S}$, Takase M \& Hayasawa H (1999) N-acylated and d enantiomer derivatives of a nonamer core peptide of lactoferricin B showing improved antimicrobial activity. Antimicrob Agents Chemother 43, $1267-1269$.

13. Yoo YC, Watanabe S, Watanabe R, Hata K, Shimazaki K \& Azuma I (1997) Bovine lactoferrin and lactoferricin, a peptide derived from bovine lactoferrin, inhibit tumor metastasis in mice. Jpn J Cancer Res 88, 184-190.

14. Bellamy WR, Wakabayashi H, Takase M, Shimamura S \& Tomita M (1993) Role of cell-binding in the antibacterial mechanism of lactoferricin B. $J$ Appl Microbiol 75, 478-484.

15. Wakabayashi H, Hiratani T, Uchida K \& Yamaguchi H (1996) Antifungal spectrum and fungicidal mechanism of an N-terminal peptide of bovine lactoferrin. J Infect Chemother 1, 185-189.

16. Valenti P, Antonini G, Siciliano R, Rega B, Superti F, Marchetti M, Ammendolia MG \& Seganti L (2000) Antiviral activity of lactoferrin derived peptides. In Lactoferrin: Structure, Function and Applications, pp. 181-186 [K Shimazaki, H Tsuda, M Tomita, T Kuwata and JP Perraudin, editors]. New York: Elsevier Publishing.

17. Andersen JH, Osbakk SA, Vorland LH, Traavik T \& Gutteberg TJ (2001) Lactoferrin and cyclic lactoferricin inhibit the entry of human cytomegalovirus into human fibroblasts. Antiviral Res 51, $141-149$.

18. Iigo M, Kuhara T, Ushida Y, Sekine K, Moore MA \& Tsuda H (1999) Inhibitory effects of bovine lactoferrin on colon carcinoma 26 lung metastasis in mice. Clin Exp Metastasis 17, 35-40.

19. Brock J (1995) Lactoferrin: a multifunctional immunoregulatory protein? Immunol Today 16, 417-419.

20. Levay PF \& Viljoen M (1995) Lactoferrin: a general review. Haematologica 80, 252-267.

21. Marieke IA, van der K, Jasper G, Kamran N, Enno CIV, Jan GMB \& Arie VNA (2004) Lactoferrampin: a novel antimicrobial peptide in the N1-domain of bovine lactoferrin. Peptides 25, $177-183$.

22. van der Kraan MI, Nazmi K, van't Hof W, Amerongen AV, Veerman EC \& Bolscher JG (2006) Distinct bactericidal activities of bovine lactoferrin peptides LFampin 268-284 and LFampin 265-284: Asp-Leu-Ile makes a difference. Biochem Cell Biol 84, 358-362.

23. Tang ZR, (2007) Study on expression of bovine lactoferricinlactoferrampin in Photorhabdus luminescens and its mechanism of action. $\mathrm{PhD}$ Thesis, Institute of Subtropical Agriculture, the Chinese Academy of Sciences, Changsha, Hunan Province, China.

24. Montagne L, Cavaney FS, Hampson DJ, Lallès JP \& Pluske JR (2004) Effect of diet composition on postweaning colibacillosis in piglets. J Anim Sci 82, 2364-2374.

25. Tang ZR, Yin YL, Nyachoti CN, et al. (2005) Effect of dietary supplementation of chitosan and galacto-mannan-oligosaccharide on serum parameters and the insulin-like growth factor-I mRNA expression in early-weaned piglets. Domest Anim Endocrinol 28, 430-441.
26. National Research Council (1998) Nutrient Requirements of Swine, 10th revised ed. Washington, DC: National Academic Press.

27. Namkung H, Gong J, Yu H \& de Lange CFM (2006) Effect of pharmacological intakes of zinc and copper on growth performance, circulating cytokines and gut microbiota of newly weaned piglets challenged with coliform lipopolysaccharides. Can J Anim Sci 86, 511-522.

28. McManus JFA (1946) Histological demonstration of mucin after periodic acid. Nature 158, 202-205.

29. Kik M, Huisman JL \& van der Poel AFB (1990) Pathologic changes of the small intestinal mucosa of pigs after feeding Phaseolus vulgaris beans. Vet Pathol 27, 329-334.

30. Callesen J, Halas D, Thorup F, Bach KKE, Kim JC, Mullan BP, Hampson DJ, Wilson RH \& Pluske JR (2007) The effects of weaning age, diet composition, and categorisation of creep feed intake by piglets on diarrhoea and performance after weaning. Livest Sci 108, 120-123.

31. Arnold RR, Cole MF \& McGhee JR (1977) A bactericidal effect for human lactoferrin. Science 197, 263-265.

32. Ellison RT, Giehl TJ \& Laforce FM (1988) Damage of the outer membrane of gram-negative bacteria by lactoferrin and transferrin. Infect Immun 56, 2774-2781.

33. Ulvatne H, Haukland HH, Olsvik O \& Vorland LH (2001) Lactoferricin B causes depolarization of the cytoplasmic membrane of Escherichia coli ATCC 25922 and fusion of negatively charged liposomes. FEBS Lett 492, 62-65.

34. Mann DM, Romm E \& Migliorini M (1994) Delineation of glycosaminoglycan-binding site in human inflammatory response protein lactoferrin. J Biol Chem 269, 23661-23667.

35. Elass-Rochard E, Roseanu A, Legrand D, Trif M, Salmon V, Motas C, Montreuil J \& Spik G (1995) Lactoferrin-lipopolysaccharide interaction: involvement of the 28-34 loop region of human lactoferrin in the high-affinity binding to Escherichia coli 055B5 lipopolysaccharide. J Biochem 312, 839-845.

36. Nikaido H \& Nakae T (1979) The outer membrane of Gramnegative bacteria. Adv Microb Physiol 20, 163-250.

37. Humphrey BD, Huang N \& Klasing KC (2002) Rice expressing lactoferrin and lysozyme has antibiotic-like properties when fed to chicks. J Nutr 132, 1214-1218.

38. Swidsinski A, Ladhoff A, Pernthaler A, et al. (2002) Mucosal flora in inflammatory bowel disease. Gastroenterology 122, 44-54.

39. Gislason J, Iyer S, Hutchens TW \& Lonnerdal B (1993) Lactoferrin receptors in piglet small intestine: lactoferrin binding properties, ontogeny, and regional distribution in the gastrointestinal tract. $J$ Nutr Biochem 4, 528-533.

40. Alessia F, Paola I \& Alessandro S (2007) Zinc, antioxidant systems and metallothionein in metal-mediated apoptosis: biochemical and cytochemical aspects. Comp Biochem Physiol C 146, 443-459.

41. Sies H (1993) Strategies of antioxidant defense. Eur J Biochem 215, 213-219.

42. Lindmark-Månsson H \& Åkesson B (2000) Antioxidative factors in milk. Br J Nutr 84, Suppl. 1, S103-S110.

43. Bihel S \& Birlouez-Aragon I (1998) Inhibition of tryptophan oxidation in the presence of iron-vitamin $\mathrm{C}$ by bovine lactoferrin. Int Dairy J 8, 637-641.

44. Bruininx EM, van der Peet-Schwering CM, Schrama JW, Vereijken PF, Vesseur PC, Everts H, den Hartog LA \& Beynen AC (2001) Individually measured feed intake characteristics and growth performance of group-housed weanling pigs: effects of sex, initial body weight, and body weight distribution within groups. J Anim Sci 79, 301-308.

45. Debbabi H, Dubarry M, Rautureau M \& Tomé D (1998) Bovine lactoferrin induces both mucosal and systemic immune response in mice. J Dairy Res 65, 283-293. 
46. Prgomet C, Prenner ML, Schwarz FJ \& Pfaffl MW (2007) Effect of lactoferrin on selected immune system parameters and the gastrointestinal morphology in growing calves. J Anim Physiol Anim Nutr 91, 109-119.

47. Shu Q, Qu F \& Gill HS (2001) Probiotic treatment using Bifidobacterium lactis HN019 reduces weanling diarrhea associated with rotavirus and Escherichia coli infection in a piglet model. J Pediatr Gastroenterol Nutr 33, 171-177.

48. Trif M, Guillen C, Vaughan DM, Elfer TJM, Brewer JM, Roseanu A \& Brock JH (2001) Liposomes as possible carriers for lactoferrin in the local treatment of inflammatory diseases. Exp Biol Med 226, 559-564.

49. Bavaye S, Elass E, Mazurier J, Spik G \& Legrand D (1999) Lactoferrin: a multifunctional glycoprotein involved in the modulation of the inflammatory process. Clin Chem Lab Med 37, 281-286.

50. Adamik B \& Walszczyk A (1996) Lactoferrin: its role in defence against infection and immunotropic properties (article in Polish). Postepy Hig Med Dosw 50, 33-41.

51. Lonnerdal B \& Iyer S (1995) Lactoferrin: molecular structure and biological function. Annu Rev Nutr 15, 93-110. 